\title{
Well Being and Occupational Stress of Women Teachers of Primary Schools
}

\author{
Dr. Utpal Kalita ${ }^{1}$
}

\section{ABSTRACT:}

The elementary school teachers and especially women teachers are facing new challenges and need to be supported by the educational administrators and the state. In order to strengthen the role of women teachers, there is needed to look at well-being and occupation stress of women teachers'. The present paper is justified to study the well being and occupational stress of women teachers of primary schools. For this, Well Being Scale and Occupational Stress Scale for are used as tools of data collection. Main findings of this study are: (i) very few women teachers fall in low well being level category while majority of the women teachers fall in the category of high well being, (ii) few women teachers fall in high stress level category while majority of the women teachers fall in the category of average as well as less stress well being category and (iii) there exists significant relationship between well being and occupational stress of women teachers of primary schools.

Keywords: Well Being, Occupational Stress, Primary Schools, Women Teachers.

Today's women are not just busy in their domestic work but are also playing others roles in the society as teachers, doctors, lawyers, engineers, astronauts, ministers etc. The role and existence of today's women is changed. She is now playing a role of working women in our society. It is generally observed that most of the working women are involved in teaching profession. Women teachers play an important role in shaping the destiny of a nation. Women teachers are more responsible as they are performing their dual duties i.e. in home as well as in an organization.

Teaching at primary stage is being affected by recruitment policy, promotions and placements. In the wake of ever increasing concern for universal elementary education, teachers' role is much more under a threatened state. The elementary school teachers and especially women teachers are facing new challenges and need to be supported by the educational administrators and the state. In order to strengthen the role of women teachers, there is needed to look at well-being and occupation stress of women teachers'. Well being requires harmony between mind and body. It implies a sense of balance and ease with the pressures in a person's life.

${ }^{1}$ Assistant Professor, Department of Education, Rangia College, Assam

(c) 2015 I U Kalita; licensee IJIP. This is an Open Access Research distributed under the terms of the Creative Commons Attribution License (http://creativecommons.org/licenses/by/2.0), which permits unrestricted use, distribution, and reproduction in any Medium, provided the original work is properly cited. 
Again occupational stress refers to physical, mental and emotional wear and tear brought about by incongruence's between two requirement of job and capabilities, and resources and need of the teacher to cope with job demands.

\section{REVIEW OF LITERATURE}

There were many studies undertaken which reveal well being and occupational stress of different samples. Few of them are mentioned below.

Belcasto and Gold (1984) studied teacher stress and burnout implications for school health personnel and concluded that occupational stress proved to be a serious health risk to teachers.

Martin and Ickovics (1987) studied the effects of stress on the psychological well being of army wives. The data supported the view that both military life stresses have important independent relationship to the general psychological well being of army wives.

Wedrich (1995) found that subjects with higher well being have less stress and strain than subjects with lower well being.

Aggarwal (2004) observed significant differences in mental, emotional and total well being of male and female teacher trainees. But urban and rural teacher trainees does not differ significantly in physical, mental, social, emotional spiritual and total well being.

\section{Justification of the Study}

The teaching profession at different stages of education i.e. elementary, secondary and tertiary gives a set of challenges in which teachers and especially women teachers demonstrate or display emotions while they may not actually feel. Teachers and especially women teachers are expected to demonstrate love and kindness to students. They are also expected to serve as mentors and motivate students who are unwilling to learn. Such kind of expectations leads to a kind of discrepancy between the expected and actual emotion of teachers leading to some kind of stress and this may be detrimental to well-being of teachers and especially women teachers. These psychological attributes are crucial for exploration to know their dynamics in the personality make up of teachers.

Further, teaching at elementary stage is also being affected by recruitment policy, promotions and placements. The school teachers in general, and at elementary stage are under heavy pressure in the wake of universalisation of elementary education and implementation of right to education for the same. In the wake of ever increasing concern, teachers' role is much more under a threatened state. The elementary school women teachers are facing new challenges and need to be supported by the educational administrators and the state. In order to strengthen the role of women teachers, there is needed to look at well-being of women teachers'. The teaching learning process, to provide quality education, is to be taken care of by teacher as all students are not in 
position of same level of learning outcome. Hence women teachers dealing with such groups of student face a high level of stress and that is detrimental to their well being. Empowerment of women teachers are not up to the mark because of their occupational stress. Hence it was thought worthwhile to undertake the present research problem.

\section{STATEMENT OF THE PROBLEM}

The research problem undertaken is entitled as "A Study on Well Being and Occupational Stress of Women Teachers of Primary Schools with Special Reference to Kamrup District, Assam".

The following terms used in the research have been defined with a view to clarify the connotation in which they are used in the present research study.

Well Being: Well-being connotes individual's feeling of contentment, happiness, satisfaction with life experiences and one's role in the world of work in terms of 'physical', 'mental', 'social', 'emotional' and 'spiritual' aspects.

Occupational Stress: Occupational Stress refers to physical, mental and emotional wear and tear brought about by incongruence between the requirement of job and capabilities, resources and need of the teacher to cope with job demands.

Women Teachers: The term refers to those women who are engaged in teaching profession.

Primary Schools: Primary schools are established under the rules and regulations framed by the Government. These are under the administrative control of Directorate of Elementary Education, Government of Assam.

\section{OBJECTIVES OF THE STUDY}

Main objectives of this study are:

1. To study the well being of women teachers of primary schools.

2. To make a comparative study on the well being of single and married women teachers of primary schools.

3. To study the occupational stress of women teachers of primary schools.

4. To make a comparative study on the occupational stress of single and married women teachers of primary schools.

5. To find out the significant relationship between well being and occupational stress of women teachers of primary schools.

\section{HYPOTHESES OF THE STUDY}

The following hypotheses are formulated to test the objective mentioned above:

1. There is no significant difference between single and married women teachers of primary schools in relation to their well being.

2. There is no significant difference between single and married women teachers of primary schools in relation to their occupational stress.

3. There is no significant relationship between well being and occupational stress of women teachers of primary schools.

\section{DELIMITATIONS OF THE STUDY}

Keeping time and resource constraints in view, the study is delimited to the following: 
i. The study was confined to women teachers of primary schools of Rani and Chhaygaon Development block of Kamrup district, Assam only.

\section{PLANS AND PROCEDURE}

a. Selection of Research Design: Considering the nature of the problem, objectives, hypotheses and the nature of data to be collected, the Descriptive Survey Method is adopted in the present study.

b. Population and Sample: The population of the present study comprises all the women teachers of primary schools of Rani and Chhaygaon Development Block, Kamrup district, Assam. The sample of the present study is selected from 20 primary schools by applying random sampling technique. From these schools, 120 women teachers have been selected as sample.

c. Research Instruments: Following instruments are applied in this research study for collection of relevant data from the sample.

i. Well Being Scale: This scale was prepared and standardized by Singh and Gupta (2001). It consisted of five sub-scale namely-physical well being, mental well being, social well being, emotional well being and spiritual well being. Each sub-scale has ten items and there are 50 items in total. It consist 29 positive items and 21 negative items. Test-retest reliability of the scale was 0.98 and split half reliability was found 0.96 . Content and concurrent validity of the Well being Scale was established.

ii. Occupational Stress Scale: This scale was prepared by Satvinder Pal Kaur (2006) which consists of 30 items. The reliability of the scale pertaining to occupational stress was established by test-retest technique which was found to be $0.86(\mathrm{~N}=50)$. To find out the construct validity, the correlation coefficient between scores of each component and the total score was calculated by the method of biserial correlation.

d. Statistical Support: The data collected through the tools was subjected to statistical analysis and results were drawn out. Simple Frequency Percentage and Mean of the total sample were computed in case of two variables; group comparisons were done by applying t-tests.

\section{ANALYSIS AND INTERPRETATION}

Objective No. 1: To study the well being of women teachers of primary schools.

Table 1: Range of Scores and Percentage of Women Teachers under Various Categories of Well Being

\begin{tabular}{|c|c|c|c|}
\hline Category & Range of Scores & N & \% \\
\hline High & $177-250$ & 76 & 63.33 \\
\hline Average & $125-176$ & 40 & 33.33 \\
\hline Low & $50-124$ & 4 & 3.34 \\
\hline
\end{tabular}

The scores of the total sample were distributed into various levels to assess respondents with high well being (177-250), average well being (125-176) and low well being (50-124). The overall view of the Table 1 depicts that very few women teachers fall in low well being level category while majority of the women teachers fall in the category of high well being and some women teachers fall in the category of average well being. 
Well Being and Occupational Stress of Women Teachers of Primary Schools

Table 2: Mean of Different Types of Well Being of Women Teachers

\begin{tabular}{|c|l|c|l|}
\hline Sl. No. & Name of Well Being & M & \multicolumn{1}{|c|}{ Remarks } \\
\hline 1. & Physical Well Being & 36.67 & More than Average \\
\hline 2. & Mental Well Being & 34.55 & More than Average \\
\hline 3. & Social Well Being & 33.89 & More than Average \\
\hline 4. & Emotional Well Being & 35.03 & More than Average \\
\hline 5. & Spiritual Well Being & 36.35 & More than Average \\
\hline 6. & Total Well Being & 176.19 & More than Average \\
\hline
\end{tabular}

From the above table, it is found that mean score of all the aspects of well being and over all well being fall under the range of more than average category. These mean score indicate that women teachers enjoy overall good sense of well being.

Objective No. 2: To make a comparative study on the well being of single and married women teachers of primary schools.

$\mathbf{H}_{\mathbf{1}}$ : There is no significant difference between single and married women teachers of primary schools in relation to their well being.

Table 3: Mean, S.Ds. and ' $t$ ' ratio for Well being of Single and Married Women Teachers of Primary Schools

\begin{tabular}{|c|c|c|c|c|c|c|c|}
\hline \multirow{2}{*}{$\begin{array}{l}\text { Sl. } \\
\text { No. }\end{array}$} & \multirow{2}{*}{ Well Being } & \multicolumn{2}{|c|}{ Single (47) } & \multicolumn{2}{|c|}{ Married (73) } & \multirow{2}{*}{ t-value } & \multirow{2}{*}{ Remarks } \\
\hline & & Mean & S.D. & Mean & S.D. & & \\
\hline 1. & Physical Well Being & 35.85 & 5.74 & 36.69 & 5.00 & 0.82 & NS \\
\hline 2. & Mental Well Being & 33.48 & 6.60 & 35.23 & 6.37 & 1.39 & NS \\
\hline 3. & Social Well Being & 33.27 & 6.29 & 34.28 & 5.94 & 0.87 & NS \\
\hline 4. & Emotional Well Being & 34.82 & 8.76 & 35.16 & 7.25 & 0.21 & NS \\
\hline 5. & Spiritual Well Being & 35.76 & 7.41 & 36.72 & 6.86 & 0.71 & NS \\
\hline 6. & Total Well Being & 173.14 & 24.02 & 178.15 & 22.69 & 1.13 & NS \\
\hline
\end{tabular}

From the above table, it is revealed that physical well being among single women teachers is higher than other aspects. And in case of married women teachers' counterpart, physical and spiritual well being is higher than other aspects. Again there exists no significant difference between single and married women teachers in case of in all the aspects of well being and over all well being. Thus, it is evident that the analysis completely accepts the null hypothesis.

Objective No. 3: To study the occupational stress of women teachers of primary schools.

Table 4: Range of Scores and Percentage of Women Teachers under Various Categories of Occupational Stress

\begin{tabular}{|c|c|c|c|}
\hline Category & Range of Scores & N & \% \\
\hline Highly Stressed & 108 and Above & 24 & 20.0 \\
\hline Average & $89-107$ & 51 & 42.5 \\
\hline Less Stressed & $30-88$ & 45 & 37.5 \\
\hline
\end{tabular}

The scores of the total sample were distributed into various levels to assess respondents with high stress (108 and above), average stress (89-107) and low stress (30-88). The overall 
view of the Table 5 depicts that few women teachers fall in high stress level category while majority of the women teachers fall in the category of average as well as less stress well being category.

Objective No. 4: To make a comparative study on the occupational stress of single and married women teachers of primary schools.

$\mathbf{H}_{2}$ : There is no significant difference between single and married women teachers of primary schools in relation to their occupational stress.

Table 5: Comparison of Occupational Stress of Single and Married Women Teachers of Primary Schools

\begin{tabular}{|c|c|c|c|c|c|}
\hline Variables & N & Mean & SD & t-ratio & Remarks \\
\cline { 1 - 4 } Single Women & 47 & 89.48 & 14.48 & \multirow{2}{*}{1.62} & NS \\
\hline Married Women & 73 & 94.04 & 15.76 & & \\
\hline
\end{tabular}

The table shows t-ratio between Mean scores of Single and Married women teachers in case of occupational stress. The t-ratio 1.62 is not significant and hence, it is said that there is no significant difference between single and married women teachers of primary schools in relation to their occupational stress. Thus, null hypothesis is accepted here.

Objective No. 5: To find out the significant relationship between well being and occupational stress of women teachers of primary schools.

$\mathbf{H}_{3}$ : There is no significant relationship between well being and occupational stress of women teachers of primary schools.

Table 6: Significant Relationship between Well Being and Occupational Stress of Women Teachers of Primary Schools

\begin{tabular}{|c|c|c|c|}
\hline Variables & N & r-ratio & Remarks \\
\hline Well Being & 120 & \multirow{2}{*}{.193} & $\begin{array}{c}\text { Significant at } \\
0.05 \text { level }\end{array}$ \\
\hline Occupational Stress & 120 & & Ondrc
\end{tabular}

The table shows r-ratio between scores of Well Being and Occupation Stress of women teachers. The r-ratio .193 is significant at 0.05 level of significant. Hence, it is said that there exists significant relationship between well being and occupational stress of women teachers of primary schools. Thus, it is evident that the analysis completely rejects the null hypothesis.

\section{FINDINGS AND DISCUSSIONS}

1) Very few women teachers fall in low well being level category while majority of the women teachers fall in the category of high well being.

2) All the aspects of well being and over all well being fall under the range of more than average category. These mean score indicate that women teachers enjoy overall good sense of well being.

3) Physical well being among single women teachers is higher than other aspects and in case of married women teachers' counterpart, physical and spiritual well being is higher than other aspects.

4) There exists no significant difference between single and married women teachers in case of in all the aspects of well being and over all well being. 
5) Few women teachers fall in high stress level category while majority of the women teachers fall in the category of average as well as less stress well being category.

6) Mean score of married women are higher than single women.

7) There is no significant difference between single and married women teachers of primary schools in relation to their occupational stress.

8) There exists significant relationship between well being and occupational stress of women teachers of primary schools.

\section{RECOMMENDATIONS}

1. Higher authorities as state government and education boards should set the curricula and make educational policies which improve the well being of elementary school teachers:

a. Teachers should be provided suitable rewards.

b. They should be provided congenial environment in the schools.

c. Teachers should be given more independence, respect and say in the decision making.

d. Boost the confidence of the teachers by way of providing better organizational conditions.

2. As overall well being of government elementary school teachers is more as compare to teachers working under panchayati raj institutions on contract basis. Thus state government must take every effort to make change in the pattern of recruitment policy and regularized services of teachers working on contract basis.

3. Coping with stress may be built with following strategies:

a. In behavioural assignments, the teachers need to be instructed to have a daily routine like thinking positively, living in the present, sharing their feelings, enjoying music etc.

b. Biofeedback, cognitive training, problem-solving skills, assertiveness etc. are effective tools for managing stress and need to be promoted among elementary school teachers which may lead to reduction in negative emotional experiences, associated with stress and improvement in creativity, achievement, productivity, quality of life and sense of well being.

4. Teacher education institutions should play a significant preventive role in developing well being, emotional intelligence, self-esteem and reducing stress by training the pupil teachers.

5. The on-going in-service teacher education programmes should be evaluated in terms of their effectiveness in developing wellness, emotional intelligence, to explore high selfesteem and techniques reducing stress among teachers far their onward transmission to new generation.

\section{CONCLUSION}

As the world is advancing technologically, organizational expectations are also increasing and due to tough competition the need for meeting these challenges has become vital. With this drive to achieve, many psychological aspects have become apparent and coping with stress is one of them. 


\section{REFERENCES}

1. Aggarwal, C. (2004). A study of psychological well being of teacher trainers in relation to personality hardiness. Unpublished M.Ed. Dissertation, Chandigarh : Panjab University.

2. Balaston, G.C. (1985). Occupational and general stress among teachers employed by selected school systems in Alabama. Dissertation Abstracts International , 46(7), p 1784

3. Best, J.W. (1993). Research in Education. (7/e) New Delhi: Prentice Hall of India Pvt. Ltd.

4. Bharathi, T. A. and Reddy, N.V. (2002). Sources of job stress among primary school teachers. Journal of Community Guidance and Research, 19(2), pp 247-253.

5. Blix, G.B. and Mitchell, R.J. (1994). Occupational stress among university teachers. Educational Research, 36, p 43.

6. Chan, D.W. (1998). Stress, coping strategies and psychological distress among secondary school teachers in Hong Kong. American Educational Research Journal, 35, pp 145-163.

7. Garret, H. E. (2005). Statistic in Psychology and Education. New Delhi: Paragon International Publisher.

8. Gyanani, T.C. (1998). Stress and strain among the teachers working in higher education institutes of different organizational climate. Indian Journal of Psychometry and Education, 29(1), pp 53-59.

9. Martin, J.A. and Ickovics J.R. (1987). The effects stress on the psychological well-being of Army wives: Initial findings from a longitudinal study. Journal of Human Stress, 13(3), pp 108-115.

10. Phillip, T.P., Bruce, W.S., Kari R.S., and Alex, J.Z (2002). Interpersonal workplace stressors and well being: A multiwave study of employees with and without arthritis. Journal of Applied Psychology, 87(4), pp 789-796. 